\title{
Sugary enhancer1 Inbreds to Improve the Quality of Sugary1 Hybrids of Sweet Corn
}

\author{
Bernardo Ordás ${ }^{2}$, Pedro Revilla, Pilar Soengas, Amando Ordás $\mathbf{1}$, and Rosa A. Malvar \\ Misión Biológica de Galicia, CSIC, Apartado 28, 36080 Pontevedra, Spain
}

AdDitional INDEX words. sweet corn, donors of favorable alleles, GCA, PTC, $\mu \mathrm{G}^{\prime}$

\begin{abstract}
Aвstract. The better emergence and seedling vigor of sweet corn (Zea mays L.) hybrids homozygous for the gene sugary1 (su1) make them more suitable for cultivation under European Atlantic conditions (cold, wet spring) than those homozygous for other traits. Elite sweet corn inbreds homozygous for both sul and sugary enhancer1 (se1) could improve the table quality of sul hybrids. The sulse1 inbreds for improving sulsul hybrid performance can be chosen in several ways. The aim of this paper was to identify donors among sulse1 inbreds that might improve the quality of sul hybrids. Eight sulse1 inbreds were crossed with eight sul inbreds that were parents of fifteen sul hybrids. Hybrids and inbreds were cultivated next to one another in two locations in northwestern Spain in 1999 and 2000. Several possible estimators for identifying sulsel inbred donors with favorable alleles lacking in the sul hybrid were determined. These estimators included the relative number of favorable alleles present in the donor but absent in the hybrid $\left(\mu \mathrm{G}^{\prime}\right)$, predicted three-way cross (PTC), minimum upper bound (UBND), net improvement (NI), probability of the net gain of favorable alleles when there is complete dominance $\left(\mathrm{PNG}_{\mathrm{g}}\right)$, probability of the net gain of favorable alleles when there is partial dominance or epistasis $\left(\mathbf{P N G}_{\mathrm{ceg}}\right)$, and general combining ability (GCA). $\mu \mathrm{G}^{\prime}$ and NI were chosen for improving hybrid table quality. These estimators indicate that table quality and other traits of sul hybrids can be improved by using germplasm from the sulse1 inbred lines. The best donor of quality for most of the hybrids was the inbred line IL731a.
\end{abstract}

Sweet corn hybrids grown in the United States are traditionally homozygous for the recessive allele sugaryl (sul). Hybrids homozygous for the shrunken2 (sh2) allele or homozygous for the sul and sugary enhancerl (sel) genes are also cultivated in temperate areas. The $s u l$ varieties are more appropriate in places where spring is cold and wet, such as the European Atlantic coast, since they have better germination characteristics than the sulsel and $s h 2$ varieties and show more early vigor (Douglass et al., 1993; Wann, 1980). Some of the sul inbreds developed in northwestern Spain (Ordás et al., 1994) and their hybrids are well adapted to European Atlantic conditions, but their table quality needs to be improved. Several studies have shown that genetic background (and not just the single genes sul, sel, or sh2) has a major influence on carbohydrate composition and therefore on table quality (Juvik et al., 1993; Soberalske and Andrew, 1978, 1980). Inbreds sulsel and sh2 might be appropriate for improving sul hybrids since their table quality is good. Sugary enhancer material is preferable to sh 2 in the short season conditions of western Europe since $s h 2$ inbred lines are difficult to maintain due to their poor germination and inconsistent field emergence.

Potential donors of table quality for sul hybrids may be identified among sulsel inbreds through the use of estimators. Several have been developed to predict inbred performance in crosses with other inbreds. General combining ability (GCA) is useful when there is a group of inbreds and it is important to know which line is the best in hybrid combination. Predicted three-way cross (PTC) has been developed to predict the best three-way hybrid that can be obtained from a group of inbreds (Sprague and Eberhart,

Received for publication 15 Mar. 2004. Accepted for publication 18 June 2004. Research supported by the National Plan for Research and Development of Spain (Project Cod. AGL2001-3946) and the Diputación Provincial de Pontevedra, Spain. Pilar Soengas and Bernardo Ordás received fellowships from the Xunta de Galicia and the Ministry of Science and Technology of Spain, respectively. ${ }^{1}$ Corresponding author; e-mail address: aordas@mbg.cesga.es.

${ }^{2}$ Present address: School of Biology, Univ. of Edinburgh, The King's Building, West Mains Road, Edinburgh EH9 3JT, U.K.
1977). Dudley $(1984,1987)$ developed estimators to be used when hybrids with superior characteristics are already available but appropriate inbred donors need to be chosen. The variable $\mu \mathrm{G}^{\prime}$ proposed by Dudley (1987) estimates the relative number of favorable alleles present in the donor but absent in the hybrid (i.e., the number of favorable alleles that the hybrid could gain). Several methods based on Dudley's theory have been developed. The minimum upper bound (UBND) (Gerloff and Smith, 1988a, $1988 \mathrm{~b}$ ) is an estimate of the relative number of favorable alleles that a hybrid might acquire. Net improvement (NI) (Bernardo, 1990) estimates the relative number of favorable alleles that the hybrid can gain from the inbred donor minus the relative number of favorable alleles that the hybrid could lose due to unfavorable alleles the donor might supply. The probability of the net gain of favorable alleles when there is complete dominance $\left(\mathrm{PNG}_{\mathrm{g}}\right)$, partial dominance or complementary epistasis $\left(\mathrm{PNG}_{\mathrm{ceg}}\right)(\mathrm{Metz}$, 1994), estimates the proportion of favorable loci with regard to the total number of loci (favorable and unfavorable) involved in a trait. $\mathrm{PNG}_{\mathrm{g}}$ is used when there is complete dominance, and $\mathrm{PNG}_{\mathrm{ceg}}$ when there is partial dominance or complementary epistasis. Several authors have compared methods of identifying donors of favorable alleles and report different estimators to be more appropriate for different materials or traits (Bernardo, 1990; Gerloff and Smith, 1988a, 1988b; Malvar et al., 1997a, 1997b, 2001; Mercy et al., 1999; Misevic, 1989a, 1989b; Zanoni and Dudley, 1989a, 1989b). Since these methods have not been tested under conditions in which sweet corn genotypes are both donors and recipients, and when the trait to improve is table quality, the evaluation of as many estimators as possible is a good idea. The aim of this paper was to identify donors among sulsel inbreds for improving the table quality of sul hybrids.

\section{Materials and Methods}

Eight sulsel inbred lines (Table 1) were evaluated as sources of favorable alleles for the improvement of $15 \mathrm{sul}$ hybrids. Five of these sulsel inbreds are known to be related to IL677a, but the 
other three lines are probably related to it as well (Table 1). Inbreds with the genetic constitution sulsel are difficult to maintain in places such as Galicia (northwestern Spain). In fact, these inbreds are the only sulsel lines we have been able to maintain under its climatic conditions. The 15 sul hybrids [EP58, EP59, EP60, and EP62 crossed with I5125, V679, V7726, and H7 (except for EP58 cross with I5125 and V7726)] chosen for improvement already showed good adaptation to European Atlantic conditions. We also included the hybrid I5125 $\times$ V7726. Four of the sul inbreds (EP58, EP59, EP60, and EP62) were obtained in northwestern Spain in a program to develop sweet corn germplasm adapted to the European Atlantic climate typical of the area (Ordás et al., 1994). The remaining sul inbreds were obtained in North America or central Europe, but have shown acceptable adaptation to the climatic conditions of northwestern Spain.

Experiments were performed in 1999 and 2000 at two locations in Galicia (northwestern Spain): Pontevedra (lat. $42^{\circ} 25^{\prime} \mathrm{N}$, long. $8^{\circ} 38^{\prime} \mathrm{W}, 20 \mathrm{~m}$ above sea level) and Pontecaldelas (lat. $42^{\circ} 23^{\prime} \mathrm{N}$, long. $8^{\circ} 32^{\prime} \mathrm{W}, 300 \mathrm{~m}$ above sea level). Unfortunately, the crop was lost to pests (Agriotes Eschscholtz) in Pontecaldelas in 2000. Both locations have a wet climate (annual rainfall $\approx 1600 \mathrm{~mm}$ ).

The 15 sul hybrids to improve along with 64 hybrids sul $\times$ sulsel made crossing eight inbreds sul (the parental inbreds of the hybrids to improve) with eight inbreds sulsel (the possible donors) (Table 1), were evaluated in an $11 \times 11$ simple lattice design that included entries for other experiments. Each singlerow experimental plot consisted of 20 hills with two kernels per hill. The rows were spaced $0.8 \mathrm{~m}$ apart, and hills $0.21 \mathrm{~m}$ apart. All hills were thinned to one plant to achieve a final plant density of $\approx 60,000$ plants/ha. Eight sul and eight sulsel inbreds (Table 1) were evaluated in separate randomized complete-block designs with four replications. The inbred trials were placed adjacent to the hybrid trials to avoid competition from hybrids. All the seed for both the experiments of hybrids and the experiments of inbreds had been obtained the previous year.

Six traits were recorded in each plot: emergence, seedling vigor, ear appearance, number of kernel rows, ear length, table quality, and soluble solid content. Seedling vigor (at the five-leaf stage), ear appearance, and table quality were measured on a subjective scale from 1 (very poor) to 9 (excellent). Average seedling vigor and ear appearance were recorded for each plot. Five trained panelists who tested three ears per plot determined table quality, that can be defined as the overall judgment on pericarp hardness, texture, and flavor of the entry. The soluble solid content of the same ears was measured with a refractometer. Emergence was measured as the number of emerged plants over sown seeds (percentage). The number of kernel rows and ear length $(\mathrm{cm})$ were determined by examining five ears taken from competitive plants from each plot (this should be sufficient since these are $F_{1}$ hybrids and highly homozygous inbreds).

Each individual hybrid trial was undertaken using either a randomized complete-block design with two replicates or an simple lattice design. When efficiency was $>105 \%$, the lattice was used; otherwise the randomized complete block was used. Means (nonadjusted for randomized complete block experiments, adjusted for block effects in lattice block experiments) were used in the analysis of variance across environments. In the combined hybrid trial, entries were assumed fixed and each location-year combination treated as a random environment. The inbred trial data were also combined across environments, considering these lines as a fixed factor and environments and replications as random effects.

For each sulsel hybrid, means for each trait across environments were used to estimate the relative number of alleles for the classes of loci defined by Dudley (1987). Dudley's model for any three homozygous lines [two parents of a hybrid (I1 and I2) and a potential donor (Iw)] considers eight classes of loci $(\mathrm{A}-\mathrm{H})$ depending on the presence of favorable alleles: in I1 - Classes A, B, C, and D, in I2-Classes A, C, E, and F, and in Iw - Classes A, $\mathrm{C}, \mathrm{E}$, and $\mathrm{G}$. The donor is chosen based on the relative number of loci in Class $\mathrm{G}\left(\mu \mathrm{G}^{\prime}\right)$ calculated following the method of Dudley (1987). Five other estimates of the value of each donor line were calculated: the predicted three-way cross $($ PTC) as $[(\mathrm{I} 1 \times \mathrm{Iw})+$ $(\mathrm{I} 2 \times \mathrm{Iw})] / 2$ (Sprague and Eberhart, 1977), the minimum UBND of $\mu \mathrm{G}$ as the minimum of the expressions (I1 $\times \mathrm{Iw})-\mathrm{I} 1$ and (I2 $\times$ Iw) - I2 (Gerloff and Smith, 1988a, 1988b), net improvement $(\mathrm{NI})$ as the maximum of $(\mathrm{I} 1 \times \mathrm{Iw})-(\mathrm{I} 1 \times \mathrm{I} 2)$ and $(\mathrm{I} 2 \times \mathrm{Iw})-(\mathrm{I} 1$ $\times$ I2) (Bernardo, 1990), net gain of favorable alleles (if there was $\left.\mathrm{PNG}_{\mathrm{g}}\right)$ as the maximum of $\mu \mathrm{G}^{\prime} /\left(\mu \mathrm{D}^{\prime}+\mu \mathrm{G}^{\prime}\right)$ and $\mu \mathrm{G}^{\prime} /\left(\mu \mathrm{F}^{\prime}\right.$ $+\mu \mathrm{G}^{\prime}$ ), and net gain of favorable alleles (if there was $\mathrm{PNG}_{\mathrm{ceg}}$ ) as the maximum of $[(\mathrm{I} 1 \times \mathrm{Iw})-\mathrm{I} 1] /[2(\mathrm{I} 1 \times \mathrm{Iw})-\mathrm{I} 1-\mathrm{Iw}]$ and [(I2 $\times \mathrm{Iw})-\mathrm{I} 2] /[2(\mathrm{I} 2 \times \mathrm{Iw})-\mathrm{I} 2-\mathrm{Iw}]($ Metz, 1994). Finally, GCA effects were calculated (Sprague and Tatum, 1942).

The standard error of each estimator was calculated as the square root of the variance of the associated linear function. Estimators were considered different from zero if their values exceeded

Table 1. Name, pedigree and origin of sul and sulsel germplasm of sweet corn used in a study for improving the quality of sul hybrids.

\begin{tabular}{|c|c|c|c|}
\hline Name & Pedigree & Name & Pedigree \\
\hline Inbreds $s u 1$ & & Inbreds sulse1 & \\
\hline EP58z & IL27a $\times$ I5125 & IL677av & ('Bolivia 1035 ' $\times$ IL44b) IL442a \\
\hline EP59z & IL27a $\times$ I5125 & IL731 $\mathrm{a}^{\mathrm{v}}$ & 'Golden Sensation' × IL677a \\
\hline $\mathrm{EP}^{2} 0^{\mathrm{z}}$ & IL27a $\times$ P51 & IL767bv & IL197a $\times$ IL677a \\
\hline EP62z & $\mathrm{I} 453 \times \mathrm{P} 51$ & IL778dv & IL557a $\times$ IL677a \\
\hline I5125y & $($ IP39 $\times$ 'Tendermost') $\times$ IP39 & IL779av & 'White Dent' $\times$ IL677a \\
\hline V679x & $\{[(\mathrm{Me} 100 \times \mathrm{V} 1) \times$ open $]$ V679 $\}$ 'Gold Cup’ & MIR225u & Closed \\
\hline V7726 $6^{x}$ & 'North Star' x 'Gold Cup' & We6 ${ }^{u}$ & Closed \\
\hline $\mathrm{H} 7 \mathrm{w}$ & 'Mainliner' & $\mathrm{We} 10 \mathrm{t}^{\mathrm{u}}$ & Closed \\
\hline
\end{tabular}

zMisión Biológica de Galicia, Pontevedra, Spain.

y Iowa Agricultural Experimental Station (obtained from Crookham Co., Caldwell, Idaho).

xHorticultural Experimental Station of Simcoe, Ontario, Canada.

wKecskmét Institute, Kecskemét, Hungary.

vUniv. of Illinois, Urbana.

uUniv. of Wisconsin, Madison. 
twice the standard error. For each estimator and each sul hybrid, donors were considered significantly different when the difference between them was greater than twice the standard error.

For each trait and sul hybrid, simple correlation coefficients were calculated for each pair of estimators of donor value, and between each estimator and the performance per se of the donor line. Correlation coefficients for each of the $15 \mathrm{sul}$ hybrids to be improved were then transformed by Fisher's z-transformation method and tested for homogeneity. When homogeneity was found, a $90 \%$ confident interval was calculated for the pooled correlation coefficient (Steel et al., 1997). All analyses were performed using the SAS package (SAS Institute, Cary, N.C.).

\section{Results and Discussion}

Correlations among estimators. Correlations involving the soluble solid content are not reported since estimates of $\mu \mathrm{G}^{\prime}$ could not be obtained for many crosses, probably due to improper assumptions of complete dominance or nonepistasis (Dudley, 1988). Correlations between $\mu \mathrm{G}^{\prime}, \mathrm{PTC}, \mathrm{UBND}$, and NI were strong and homogeneous for most traits (Table 2). The strong correlations between $\mu \mathrm{G}^{\prime}$, PTC, and UBND indicate that these estimators are similar because they are all mainly based on class G. For some hybrids, PTC and UBND can overestimate the number of class $\mathrm{G}$ loci in some inbred donors, so $\mu \mathrm{G}^{\prime}$ was used to select the donors as it is a more sound estimator than PTC and UBND from the theoretical point of view (Zanoni and Dudley, 1989a). However, the strong average correlation between $\mu \mathrm{G}^{\prime}$ and NI indicates that, in general, the probability of gaining favorable alleles is stronger than the probability of losing them, although just how strong this probability is depends on the hybrid in question. It was therefore deemed appropriate to calculate $\mu \mathrm{G}^{\prime}$ and NI for all the hybrids. GCA and $\mathrm{PNG}_{\mathrm{g}}$ correlated weakly with the previous estimators, especially $\mathrm{PNG}_{\mathrm{g}}$ with table quality. The correlations of $\mathrm{PNG}_{\mathrm{g}}$ with other estimators were heterogeneous for several traits. GCA gave a different estimation because it takes into account all the hybrids at once rather than each hybrid separately; therefore, it detected which inbred would be the best donor across the range of hybrids. For some hybrids, $\mathrm{PNG}_{\mathrm{g}}$ gave either an erroneous estimate (when the performance of some donor inbred was very poor) or was unable to detect differences between donors since for all of them it approached a value of one. The correlations between PNG $_{\text {ceg }}$ and Iw with the other estimators were weak for all traits since the "expectations" for $\mathrm{PNG}_{\text {ceg }}$ and Iw contain all loci classes while others mainly take into account the $\mathrm{G}$ loci class. In addition, both $\mathrm{PNG}_{\mathrm{ceg}}$ and $\mathrm{PNG}_{\mathrm{g}}$ gave erroneous estimates when some of the donor inbreds performed poorly. The correlation coefficients among estimators obtained in this study were similar to those found by other authors (Bernardo, 1990; Gerloff and Smith, 1988a, 1988b; Malvar et al., 1997a, 1997b; Metz, 1994; Misevic, 1989a, 1989b; Zanoni and Dudley, 1989a, 1989b).

We therefore chose donor lines based on the $\mu \mathrm{G}^{\prime}$ values, which estimates the number of favorable alleles a hybrid can gain. Donors with $\mu \mathrm{G}^{\prime}$ significantly greater than zero can improve the hybrid, while donors with $\mu \mathrm{G}^{\prime}$ values not significantly different to zero cannot. Donor inbreds were also chosen based on NI values since this takes into account the unfavorable alleles present in the donors. The unfavorable alleles complicate the isolation of superior new lines, and more crosses are required to obtain a good result.

INBREDS AND HYBRIDS: DIFFERENCES BETWEEN TRAITS. Significant differences were seen in emergence and table quality among the sulse1 inbreds (Table 3). IL767b was the worst for emergence, but the best for table quality. There were no significant differences among the inbreds with respect to soluble solid content, even though this trait is related to table quality since the solids in question are largely sugars (Scott et al., 1945). Rhodes et al. (1982) found no difference in sugar content among IL731a, IL778d, IL779a, and IL677a, but IL767b had less sugar. In the present study, however, it showed the best table quality. The lack of a relationship between sugar concentration and organoleptic scores has also been reported by other authors (Evensen and Boyer, 1986; Revilla, 1992) who thought that in the presence of adequate sugar, other factors would most influence table quality.

The emergence and seedling vigor of some of the sul hybrids was acceptable, especially those of EP62 × V679 and EP62 $\times$ V7726 (Table 3), indicating that they are better adapted to European Atlantic conditions. Most of the hybrids received scores of 5 or 6 for ear appearance, had $<16$ rows of kernels (the advisable minimum) (Tracy, 2001), an ear length of $<20-23 \mathrm{~cm}$ (the advisable value) (Tracy, 2001), and a table quality of $<5$ (Table $3)$. Therefore, all the hybrids had quality values that needed to be improved. We chose to improve EP62 × V679, EP62 × V7726, $\mathrm{EP} 60 \times \mathrm{V} 7726, \mathrm{EP} 58 \times \mathrm{H} 7$, and $\mathrm{I} 5125 \times \mathrm{V} 7726 . \mathrm{EP} 62 \times \mathrm{V} 679$ and EP62 $\times$ V7726 showed the best emergence and seedling vigor. EP60 $\times$ V7726 showed good agricultural performance and the best table quality. In addition, it is important to improve the very low number of rows of kernels for these hybrids $(\approx 13$ or 14). EP58 $\times$ H7 was the best for ear appearance and number of rows of kernels (so it is not necessary to improve these traits), and showed good agricultural performance. Finally, I5125 × V7726 showed an adequate number of rows of kernels.

CHOICE OF DONORS. For some traits, estimates of $\mu \mathrm{G}^{\prime}$ could not be obtained for some donors (Table 4), probably because of incorrect assumptions regarding complete dominance or non-epistasis (Dudley, 1988). This is clear for the number of rows of kernels, which in many studies has been shown to be an additive trait (Hallauer and Miranda, 1988). Other authors report $\mu \mathrm{G}^{\prime}$ could not be calculated for grain dry matter (Zanoni and Dudley, 1989a) and early vigor (Malvar et al., 1997b). However, $\mu \mathrm{G}^{\prime}$ for ear length [which is supposed to fit the Dudley model (Dudley, 1998)] could be calculated for all donors. Malvar et al. (1997a) also calculated $\mu \mathrm{G}^{\prime}$ for ear length in all donors.

Ear appearance and table quality would be easy to improve in most of the hybrids (NI was significantly higher than zero for most donors), although for hybrids with the highest values for these traits $(\mathrm{EP} 58 \times \mathrm{H} 7$ and EP60 $\times$ V7726) this would be more difficult (as expected) (Table 4). For EP58 $\times$ H7, no single donor had NI values above zero, and most donors did not even have favorable alleles. For EP60 × V7726, only IL731a had an NI value significantly higher than zero. Dudley (1987) also found that $\mu \mathrm{G}^{\prime}$ values were lower for the higher yielding hybrids. The ear length and number of rows of kernels of all the hybrids could be easily improved by most of the donors (NI was significantly greater than zero for most of the donors) (Table 4).

The best course of action would be to improve all traits at the same time, but if that is impossible, traits deemed more important should be improved while the performance of others is maintained. To achieve this, it would seem appropriate to first choose those donors that improve the most important traits and, from among them, those most likely to improve the other characteristics as well. In the present study, the most important trait was table quality. For EP60 × V7726, the inbreds IL731a and We6 were the only donors with favorable alleles for table 
Table 2. Pooled correlations among $\mu \mathrm{G}^{\prime}$, PTC, UBND, NI, $\mathrm{PNG}_{\mathrm{g}}, \mathrm{PNG}_{\mathrm{ceg}}$, GCA ${ }^{z}$, and inbred per se performance, plus $90 \%$ confidence intervals (brackets), for ear appearance (A), number of kernel rows (R), ear size (S), and table quality (Q) obtained from three experiments of sweet corn grown in Galicia (northwestern Spain).

\begin{tabular}{|c|c|c|c|c|c|c|c|}
\hline Trait & PTC & UBND & $\mathrm{NI}$ & $\mathrm{PNG}_{\mathrm{g}}$ & $\mathrm{PNG}_{\mathrm{ceg}}$ & GCA & Perse \\
\hline$\overline{\mu \mathrm{G}^{\prime}}$ & & & & & & & \\
\hline \multirow[t]{2}{*}{ A } & 0.99 & 0.95 & 0.94 & $0.61^{*}$ & -0.12 & 0.88 & 0.02 \\
\hline & (0.98 0.99$)$ & (0.91 0.97$)$ & $(0.900 .96)$ & & $(-0.350 .12)$ & $\left(\begin{array}{lll}0.80 & 0.92)\end{array}\right.$ & $(-0.220 .26)$ \\
\hline \multirow[t]{2}{*}{$\mathrm{R}$} & 0.97 & 0.99 & 0.99 & 0.33 & -0.22 & 0.90 & 0.39 \\
\hline & (0.94 0.99$)$ & (0.97 0.99) & (0.97 0.99) & $(-0.050 .63)$ & $(-0.550 .17)$ & $(0.790 .95)$ & (0.01 0.67$)$ \\
\hline \multirow[t]{2}{*}{ S } & 0.99 & 0.96 & 0.96 & $0.68^{*}$ & -0.45 & 0.95 & -0.50 \\
\hline & (0.98 0.99$)$ & (0.95 0.98$)$ & (0.94 0.97) & & $(-0.59-0.28)$ & (0.92 0.96) & $(-0.63-0.34)$ \\
\hline \multirow[t]{2}{*}{ Q } & 0.98 & 0.97 & 0.96 & $-0.10^{*}$ & 0.29 & 0.84 & 0.41 \\
\hline & (0.95 0.99$)$ & (0.94 0.98$)$ & (0.93 0.98$)$ & & $(-0.020 .55)$ & $(0.720 .91)$ & (0.12 0.64) \\
\hline \multicolumn{8}{|l|}{ PTC } \\
\hline \multirow[t]{2}{*}{ A } & & 0.92 & 0.90 & $0.61^{*}$ & -0.13 & 0.88 & -0.01 \\
\hline & & $\left(\begin{array}{lll}0.89 & 0.95)\end{array}\right.$ & (0.86 0.93$)$ & & $(-0.320 .07)$ & 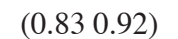 & $(-0.210 .18)$ \\
\hline \multirow[t]{2}{*}{$\mathrm{R}$} & & 0.95 & 0.93 & 0.43 & -0.34 & 0.84 & 0.22 \\
\hline & & (0.92 0.96$)$ & $\left(\begin{array}{lll}0.90 & 0.95)\end{array}\right.$ & (0.06 0.70$)$ & $(-0.51-0.16)$ & (0.78 0.89$)$ & (0.03 0.40$)$ \\
\hline \multirow[t]{2}{*}{ S } & & 0.96 & 0.96 & $0.71^{*}$ & -0.47 & 0.95 & -0.51 \\
\hline & & (0.93 0.97$)$ & (0.94 0.97) & & $(-0.61-0.30)$ & (0.93 0.97$)$ & $(-0.64-0.35)$ \\
\hline \multirow[t]{2}{*}{ Q } & & 0.93 & 0.93 & $-0.03^{*}$ & 0.23 & 0.85 & 0.32 \\
\hline & & (0.90 0.95$)$ & $\left(\begin{array}{lll}0.90 & 0.95)\end{array}\right.$ & & (0.04 0.41$)$ & (0.78 0.90$)$ & (0.13 0.48$)$ \\
\hline \multicolumn{8}{|l|}{ UBND } \\
\hline \multirow[t]{2}{*}{ A } & & & 0.67 & $0.36^{*}$ & -0.12 & 0.78 & 0.02 \\
\hline & & & (0.55 0.77$)$ & & $\left(\begin{array}{lll}-0.31 & 0.08)\end{array}\right.$ & (0.69 0.85$)$ & $(-0.170 .22)$ \\
\hline \multirow[t]{2}{*}{$\mathrm{R}$} & & & 0.98 & 0.32 & -0.34 & 0.77 & 0.06 \\
\hline & & & (0.97 0.99$)$ & $(-0.070 .62)$ & $(-0.50-0.15)$ & $(0.670 .84)$ & $(-0.140 .25)$ \\
\hline \multirow[t]{2}{*}{ S } & & & $0.88^{*}$ & $0.46^{*}$ & -0.39 & 0.91 & -0.41 \\
\hline & & & & & $(-0.54-0.21)$ & (0.87 0.94$)$ & $(-0.56-0.24)$ \\
\hline \multirow[t]{2}{*}{ Q } & & & 0.86 & $-0.06^{*}$ & 0.21 & 0.77 & 0.44 \\
\hline & & & $\left(\begin{array}{lll}0.80 & 0.91)\end{array}\right.$ & & (0.010.39) & (0.67 0.84$)$ & $(0.260 .58)$ \\
\hline \multicolumn{8}{|l|}{ NI } \\
\hline A & & & & $0.82^{*}$ & 0.03 & 0.66 & -0.06 \\
\hline & & & & & $(-0.090 .15)$ & $(0.580 .72)$ & $(-0.180 .07)$ \\
\hline $\mathrm{R}$ & & & & 0.30 & 0.21 & 0.70 & 0.13 \\
\hline & & & & $(-0.090 .61)$ & (0.09 0.32$)$ & (0.63 0.76$)$ & $\left(\begin{array}{lll}0.01 & 0.25\end{array}\right)$ \\
\hline S & & & & $0.83^{*}$ & -0.11 & 0.87 & -0.35 \\
\hline & & & & & $(-0.230 .01)$ & $(0.840 .90)$ & $(-0.45-0.24)$ \\
\hline Q & & & & $0.16^{*}$ & 0.11 & 0.78 & 0.20 \\
\hline & & & & & $\left(\begin{array}{lll}-0.01 & 0.23\end{array}\right)$ & $\left(\begin{array}{lll}0.73 & 0.82\end{array}\right)$ & $\left(\begin{array}{lll}0.08 & 0.32\end{array}\right)$ \\
\hline $\mathrm{PNG}_{\mathrm{g}}$ & & & & & & & \\
\hline$A^{-g}$ & & & & & 0.03 & $0.64^{*}$ & 0.05 \\
\hline & & & & & $\left(\begin{array}{lll}-0.21 & 0.27\end{array}\right)$ & & $(-0.190 .29)$ \\
\hline $\mathrm{R}$ & & & & & -0.25 & 0.07 & -0.08 \\
\hline & & & & & $(-0.570 .14)$ & $(-0.320 .44)$ & $(-0.440 .31)$ \\
\hline S & & & & & -0.38 & $0.66^{*}$ & -0.34 \\
\hline & & & & & $(-0.53-0.20)$ & & $(-0.50-0.16)$ \\
\hline Q & & & & & -0.07 & $-0.18^{*}$ & -0.07 \\
\hline & & & & & $(-0.370 .24)$ & & $(-0.360 .25)$ \\
\hline $\mathrm{PNG}_{\mathrm{ceg}}$ & & & & & & & \\
\hline A & & & & & & 0.04 & $0.88^{*}$ \\
\hline & & & & & & $(-0.080 .16)$ & \\
\hline $\mathrm{R}$ & & & & & & 0.12 & 0.16 \\
\hline & & & & & & $\left(\begin{array}{lll}-0.01 & 0.24)\end{array}\right.$ & $(0.040 .28)$ \\
\hline S & & & & & & -0.12 & $0.90^{*}$ \\
\hline & & & & & & $(-0.240 .00)$ & \\
\hline Q & & & & & & 0.06 & $0.09^{*}$ \\
\hline & & & & & & $(-0.070 .18)$ & \\
\hline GCA & & & & & & & \\
\hline A & & & & & & & -0.04 \\
\hline $\mathrm{R}$ & & & & & & & 0.05 \\
\hline S & & & & & & & -0.37 \\
\hline Q & & & & & & & 0.26 \\
\hline
\end{tabular}

${ }^{z} \mu \mathrm{G}^{\prime}=$ relative number of favorable alleles (Dudley, 1987); PTC = predicted three-way cross (Sprague and Eberhart, 1977); UBND = minimum upper bound (Gerloff and Smith, 1988a); NI = net improvement (Bernardo, 1990); PNG $_{\mathrm{g}}=$ probability of the net gain of favorable alleles when there is complete dominance (Metz, 1994); $\mathrm{PNG}_{\mathrm{ceg}}=$ probability of the net gain of favorable alleles when there is partial dominance or complementary epistasis (Metz, 1994); GCA = general combining ability (Sprague and Tatum, 1942).

*Heterogeneous at the $5 \%$ probability. 
Table 3. Emergence, seedling vigor, ear appearance, number of kernel rows, ear length, and table quality for eight inbreds and 15 hybrids of sweet corn grown in three environments in Galicia (northwestern Spain).

\begin{tabular}{|c|c|c|c|c|c|c|}
\hline & $\begin{array}{c}\text { Emergence } \\
(\%)\end{array}$ & $\begin{array}{c}\text { Seedling } \\
\text { vigor } \\
(1-9)^{z}\end{array}$ & $\begin{array}{c}\text { Ear } \\
\text { appearance } \\
(1-9)^{\mathrm{z}}\end{array}$ & $\begin{array}{l}\text { Kernel } \\
\text { rows } \\
\text { (no.) }\end{array}$ & $\begin{array}{c}\text { Ear } \\
\text { length } \\
(\mathrm{cm}) \\
\end{array}$ & $\begin{array}{l}\text { Table } \\
\text { quality } \\
(1-9)^{z}\end{array}$ \\
\hline & \multicolumn{6}{|c|}{ Inbreds sulsel } \\
\hline IL677a & 11 & 1.5 & 3.8 & 15.4 & 13.6 & 5.9 \\
\hline IL731a & 14 & 2.1 & 4.4 & 15.0 & 14.5 & 5.9 \\
\hline IL767b & 4 & 2.1 & 3.7 & 14.8 & 13.2 & 7.1 \\
\hline IL778d & 16 & 3.0 & 4.1 & 13.4 & 13.4 & 5.8 \\
\hline IL779a & 29 & 2.4 & 2.7 & 14.3 & 11.7 & 5.1 \\
\hline MIR225 & 30 & 3.3 & 3.8 & 14.3 & 12.4 & 5.2 \\
\hline We10t & 28 & 2.0 & 4.0 & 15.4 & 14.5 & 5.4 \\
\hline We6 & 29 & 2.1 & 5.0 & 15.6 & 15.5 & 4.8 \\
\hline \multirow{2}{*}{$\mathrm{LSD}_{0.05}$} & 17 & & & & & 0.7 \\
\hline & \multicolumn{6}{|c|}{ Hybrids sul } \\
\hline EP58 $\times$ V679 & 53 & 4.4 & 4.8 & 17.7 & 15.8 & 4.4 \\
\hline EP58 $\times$ H7 & 69 & 6.4 & 6.8 & 20.3 & 17.4 & 3.9 \\
\hline EP59 $\times$ I5125 & 71 & 5.0 & 5.1 & 15.5 & 16.1 & 4.1 \\
\hline EP59 × V679 & 60 & 4.9 & 4.7 & 14.1 & 16.3 & 4.6 \\
\hline EP59 × V7726 & 66 & 5.8 & 6.3 & 13.4 & 18.2 & 5.3 \\
\hline EP59 × H7 & 73 & 4.8 & 6.2 & 16.2 & 17.5 & 4.3 \\
\hline $\mathrm{EP} 60 \times \mathrm{I} 5125$ & 54 & 5.5 & 5.4 & 15.5 & 16.7 & 4.1 \\
\hline EP60 × V679 & 48 & 5.6 & 4.9 & 14.1 & 15.7 & 4.3 \\
\hline $\mathrm{EP} 60 \times \mathrm{V} 7726$ & 71 & 6.3 & 5.3 & 13.9 & 16.8 & 5.6 \\
\hline $\mathrm{EP} 60 \times \mathrm{H} 7$ & 68 & 6.7 & 5.7 & 15.2 & 17.1 & 3.7 \\
\hline EP62 × I5125 & 49 & 4.7 & 5.2 & 15.0 & 16.3 & 4.5 \\
\hline EP62 × V679 & 85 & 8.2 & 5.6 & 13.9 & 17.0 & 5.1 \\
\hline EP62 × V7726 & 75 & 6.9 & 4.8 & 13.1 & 17.4 & 4.5 \\
\hline $\mathrm{EP} 62 \times \mathrm{H} 7$ & 39 & 5.1 & 5.4 & 14.4 & 17.6 & 3.1 \\
\hline $\mathrm{I} 5125 \times \mathrm{V} 7726$ & 73 & 5.1 & 6.2 & 18.2 & 16.6 & 4.4 \\
\hline $\mathrm{LSD}_{0.05}$ & 19 & 1.3 & 1.0 & 0.9 & 1.4 & 0.8 \\
\hline
\end{tabular}

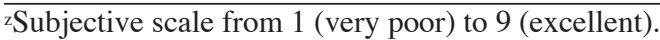

quality. IL731a had an NI value significantly above zero while We6 did not, so it is easier to improve this quality with IL731a. For the ear traits, this inbred had NI values significantly greater than zero, so it would also be easy to improve these characteristics with IL731a. The improvement of table quality and the ear characteristics of EP62 $\times$ V7726 should be easily achieved with IL731a, IL767b, and IL779a since the NIs were significantly greater than zero. IL731a was the best donor for table quality, so it is preferred over the other two (although the difference was not significant). Improving the quality of EP62 $\times$ V679 would be impossible with any of the present donors; other sources of germplasm must therefore be sought. The improvement of table quality and the ear characteristics of I5125 $\times$ V7726 should be easy to improve with IL677a, IL731a, and We6. Finally, for EP58 $\times \mathrm{H} 7$, some inbreds could improve all characteristics. Table quality could be easily improved by most of the donors examined (NI significantly higher than zero), but ear appearance could not be easily improved by any of them (NI not significantly higher than zero). This result was expected since EP58 $\times$ H7 had one of the worst table qualities but the best ear appearance. Among the donor inbreds, IL767b stood out for all traits.

The best donor for table quality for most of the hybrids would be IL731a, although it had an intermediate per se value. We6 would also a good donor for some hybrids, but it had the worst per se value. This is because IL731a and We6 have less total favorable alleles for table quality (A, C, E, and G classes) than the other inbreds, but they have more favorable alleles that are absent in the hybrid ( $\mathrm{G}$ class) than do the rest of the inbreds. Therefore, as other authors have indicated for characteristics such as yield, plant height or earliness (Malvaretal., 1997a, 1997b; Misevic, 1989a; Zanoni and Dudley, 1989a), it would not be advisable to simply choose the inbred donor with the best table quality for improving that of a hybrid, but to select the donor with the most favorable allele estimators.

Although only three environments were tested, a large number of hybrids were used. This, therefore, allows conclusions to be drawn with a reasonable degree of confidence. The next step should be to use a smaller number of donors; this will allow experiments to be performed in more environments.

The sulsel inbreds seem to be a promising source of germplasm for improving these characteristics in sul hybrids. Their use might allow more commercially viable sweet corn varieties, capable of growing in European Atlantic climatic conditions, to be obtained. A possible way to improve a sul hybrid would be to cross one of its parental inbreds to the donor, self the $F_{1}$, cross the $\mathrm{S}_{1} \mathrm{~s}$ to the other parental inbred, and test the crosses to identify those that have better quality than the original hybrid. Early testing can be used to shorten the length of the program as we are dealing with elite material. Remnant seed of the selected $S_{1}$ s would then be selfed for several seasons until reaching homozygosis.

\section{Literature Cited}

Bernardo, R. 1990. An alternative statistic for identifying lines useful for improving parents of an elite single cross. Theor. Appl. Genet. 80:105-109.

Douglass, S.K., J.A. Juvik, and W.E. Splittstoesser. 1993. Sweet corn seedling emergence and variation in kernel carbohydrate reserves. Seed Sci Technol. 21:433-445.

Dudley, J.W. 1984. A method of identifying lines for use in improving parents of a single cross. Crop Sci. 24:355-357.

Dudley, J.W. 1987. Modification of methods for identifying inbred lines useful for improving parents of elite single crosses. Crop Sci. 27:944-947.

Dudley, J.W. 1988. Theory for identification of lines or populations useful for improvement of elite single crosses, p. 451-461. In: B. Weir (ed.). Proc. 2nd Intl. Conf. Quant. Genetics, Raleigh, N.C. 1-5 June 1987. Sinauer Assoc., Sunderland, Mass.

Evensen, K.B. and C.D. Boyer. 1986. Carbohydrate composition and sensory quality of fresh and stored sweet corn. J. Amer. Soc. Hort. Sci. 111:734-738.

Gerloff, J.E. and O.S. Smith. 1988a. Choice of method for identifying germplasm with superior alleles 1 . Theoretical results. Theor. Appl. Genet. 76:209-216.

Gerloff, J.E. and O.S. Smith. 1988b. Choice of method for identifying germplasm with superior alleles 2. Computer simulation results. Theor. Appl. Genet. 76:217-227.

Hallauer, A.R. and J.B. Miranda, Jr. 1988. Quantitative genetics in maize breeding. 2nd ed. Iowa State Univ. Press, Ames.

Juvik, J.A., M.C. Jangulo, J.M. Headrick, J.M. Pataky, and W.F. Tracy. 
Table 4. Estimates of relative number of favorable alleles $\left(\mu \mathrm{G}^{\mathrm{z}}\right)$ and net improvement $\left(\mathrm{NI}^{\mathrm{z}}\right)$ for ear appearance (A), ear length $(\mathrm{S})$, row number $(\mathrm{R})$, and table quality $(\mathrm{Q})$ for eight sulse1 inbreds of sweet corn evaluated as sources of favorable alleles to improve five sul hybrids. Data obtained from three environments in Galicia (northwestern Spain).

\begin{tabular}{|c|c|c|c|c|c|c|c|c|c|}
\hline & & IL677a & IL731a & IL767b & IL778d & IL779a & MIR225 & We6 & We10t \\
\hline \multicolumn{10}{|c|}{$E P 60 \times V 7726$} \\
\hline \multirow[t]{2}{*}{ A } & $\mu \mathrm{G}^{\prime}$ & $\S^{y}$ & $0.94 \mathrm{ab}^{*}$ & $0.77 \mathrm{ab}^{*}$ & $\ddagger^{x}$ & $1.22 b^{*}$ & $\ddagger$ & $1.13 b^{*}$ & $0.60 \mathrm{a}^{*}$ \\
\hline & NI & $0.99 \mathrm{ab}^{*}$ & $1.10 \mathrm{~b}^{*}$ & $0.89 \mathrm{ab}^{*}$ & $\ddagger$ & $1.03 \mathrm{~b}^{*}$ & $\neq$ & $1.05 \mathrm{~b}^{*}$ & $0.32 \mathrm{a}$ \\
\hline \multirow[t]{2}{*}{ S } & $\mu \mathrm{G}^{\prime}$ & $1.54 \mathrm{a}^{*}$ & $1.31 \mathrm{a}^{*}$ & $1.49 \mathrm{a}^{*}$ & $\ddagger$ & $2.51 b^{*}$ & \$ & $1.43 \mathrm{a}^{*}$ & $0.98 \mathrm{a}^{*}$ \\
\hline & NI & $0.87 \mathrm{ab}^{*}$ & $1.14 \mathrm{ab}^{*}$ & $1.38 \mathrm{~b}^{*}$ & $\ddagger$ & $1.89 \mathrm{~b}^{*}$ & $\ddagger$ & $0.90 \mathrm{ab}^{*}$ & $0.10 \mathrm{a}$ \\
\hline \multirow[t]{2}{*}{$\mathrm{R}$} & $\mu \mathrm{G}^{\prime}$ & $0.93 \mathrm{a}^{*}$ & $\S$ & $\S$ & $\ddagger$ & $\S$ & $\neq$ & $\S$ & $0.90 \mathrm{a}^{*}$ \\
\hline & NI & $1.26 b^{*}$ & $1.03 \mathrm{ab}^{*}$ & $0.30 \mathrm{a}$ & $\ddagger$ & $1.46 b^{*}$ & \$ & $1.40 \mathrm{~b}^{*}$ & $1.00 \mathrm{ab}^{*}$ \\
\hline \multirow[t]{3}{*}{ Q } & $\mu \mathrm{G}^{\prime}$ & $0.18 \mathrm{ab}$ & $0.67 \mathrm{c}^{*}$ & $0.24 \mathrm{abc}$ & $\dagger$ & $0.07 \mathrm{ab}$ & $\ddagger$ & $0.37 \mathrm{bc}^{*}$ & $-0.19 \mathrm{a}$ \\
\hline & NI & $-0.03 \mathrm{ab}$ & $0.45 b^{*}$ & $0.02 \mathrm{ab}$ & $\ddagger$ & $-0.04 \mathrm{ab}$ & $\ddagger$ & $0.24 \mathrm{ab}$ & $-0.33 \mathrm{a}$ \\
\hline & \multicolumn{9}{|c|}{$E P 62 \times V 7726$} \\
\hline \multirow[t]{2}{*}{ A } & $\mu \mathrm{G}^{\prime}$ & $\S$ & $\S$ & $\S$ & $\ddagger$ & $\S$ & $\ddagger$ & $\S$ & $\S$ \\
\hline & NI & $1.24 \mathrm{ab}$ & $1.35 \mathrm{~b}^{*}$ & $1.13 \mathrm{ab}$ & $\ddagger$ & $1.27 \mathrm{~b}$ & $\neq$ & $1.30 \mathrm{~b}^{*}$ & $0.56 \mathrm{a}$ \\
\hline \multirow[t]{2}{*}{ S } & $\mu \mathrm{G}^{\prime}$ & $0.99 \mathrm{a}^{*}$ & $1.16 \mathrm{a}^{*}$ & $1.16 \mathrm{a}^{*}$ & $\ddagger$ & $1.96 b^{*}$ & $\neq$ & $0.97 \mathrm{a}^{*}$ & $0.59 \mathrm{a}^{*}$ \\
\hline & NI & $0.56 \mathrm{ab}$ & $0.84 \mathrm{ab}^{*}$ & $1.07 \mathrm{~b}^{*}$ & $\ddagger$ & $1.59 \mathrm{~b}^{*}$ & $\ddagger$ & $0.60 \mathrm{ab}$ & $-0.03 \mathrm{a}$ \\
\hline \multirow[t]{2}{*}{$\mathrm{R}$} & $\mu \mathrm{G}^{\prime}$ & $\S$ & $\S$ & $\S$ & $\ddagger$ & $\S$ & $\ddagger$ & $\S$ & $\S$ \\
\hline & NI & $1.63 \mathrm{~b}^{*}$ & $1.40 \mathrm{ab}^{*}$ & $0.66 \mathrm{a}^{*}$ & $\dagger$ & $1.83 b^{*}$ & 末 & $1.76 b^{*}$ & $1.60 b^{*}$ \\
\hline \multirow[t]{3}{*}{ Q } & $\mu \mathrm{G}^{\prime}$ & $0.48 a^{*}$ & $0.73 \mathrm{a}^{*}$ & $0.54 \mathrm{a}^{*}$ & $\ddagger$ & $\S$ & $\neq$ & $\S$ & $\S$ \\
\hline & NI & $0.55 \mathrm{ab}^{*}$ & $0.80 \mathrm{~b}^{*}$ & $0.61 \mathrm{ab}^{*}$ & $\ddagger$ & $0.54 \mathrm{ab}^{*}$ & $\ddagger$ & $0.66 \mathrm{ab}^{*}$ & $0.08 \mathrm{a}$ \\
\hline & & & & & $E P 62 \times V 6$ & & & & \\
\hline \multirow[t]{2}{*}{ A } & $\mu \mathrm{G}^{\prime}$ & $0.20 \mathrm{a}$ & $\ddagger$ & $0.53 \mathrm{a}^{*}$ & $0.53 \mathrm{a}^{*}$ & $0.52 \mathrm{a}^{*}$ & 末 & $\neq$ & $0.10 \mathrm{a}$ \\
\hline & NI & $-0.06 \mathrm{a}$ & $\ddagger$ & $0.45 \mathrm{a}$ & $0.18 \mathrm{a}$ & $0.30 \mathrm{a}$ & $\neq$ & $\neq$ & $-0.01 \mathrm{a}$ \\
\hline \multirow[t]{2}{*}{ S } & $\mu \mathrm{G}^{\prime}$ & $0.92 \mathrm{ab}^{*}$ & $\ddagger$ & $1.57 \mathrm{bc}^{*}$ & $1.34 \mathrm{abc}^{*}$ & $1.77 \mathrm{c}^{*}$ & $\neq$ & $\neq$ & $0.61 \mathrm{a}^{*}$ \\
\hline & NI & $0.42 \mathrm{ab}$ & $\ddagger$ & $1.26 b^{*}$ & $0.70 \mathrm{ab}$ & $1.20 \mathrm{~b}^{*}$ & $\neq$ & \$ & $-0.01 \mathrm{a}$ \\
\hline \multirow[t]{2}{*}{$\mathrm{R}$} & $\mu \mathrm{G}^{\prime}$ & $\S$ & $\ddagger$ & $\S$ & $0.56 \mathrm{a}^{*}$ & $\S$ & $\neq$ & $\neq$ & $1.09 \mathrm{a}^{*}$ \\
\hline & NI & $1.43 b^{*}$ & $\dagger$ & $1.10 \mathrm{ab}^{*}$ & $0.66 \mathrm{a}^{*}$ & $1.30 \mathrm{ab}^{*}$ & $\neq$ & $\ddagger$ & $1.20 \mathrm{ab}^{*}$ \\
\hline \multirow[t]{3}{*}{ Q } & $\mu \mathrm{G}^{\prime}$ & $0.08 \mathrm{a}$ & $\ddagger$ & $0.28 \mathrm{a}$ & $0.05 \mathrm{a}$ & $0.07 \mathrm{a}$ & $\neq$ & $\neq$ & $0.23 \mathrm{a}$ \\
\hline & NI & $-0.08 \mathrm{a}$ & $\ddagger$ & $0.11 \mathrm{a}$ & $-0.01 \mathrm{a}$ & $-0.09 \mathrm{a}$ & $\neq$ & + & $0.06 \mathrm{a}$ \\
\hline & \multicolumn{9}{|c|}{$I 5125 \times V 7726$} \\
\hline \multirow[t]{2}{*}{ A } & $\mu \mathrm{G}^{\prime}$ & $1.01 \mathrm{~b}^{*}$ & $0.89 b^{*}$ & $0.74 \mathrm{ab}^{*}$ & $\ddagger$ & \$ & $\neq$ & $1.01 \mathrm{~b}^{*}$ & $0.34 \mathrm{a}$ \\
\hline & NI & $0.52 a b^{*}$ & $0.63 b^{*}$ & $0.20 \mathrm{ab}$ & $\ddagger$ & $\neq$ & $\neq$ & $0.58 b^{*}$ & $-0.14 \mathrm{a}$ \\
\hline \multirow[t]{2}{*}{ S } & $\mu \mathrm{G}^{\prime}$ & $1.70 \mathrm{ab}^{*}$ & $1.65 \mathrm{ab}^{*}$ & $2.22 b^{*}$ & $\ddagger$ & + & $\neq$ & $1.52 \mathrm{ab}^{*}$ & $1.03 \mathrm{a}^{*}$ \\
\hline & NI & $0.94 \mathrm{ab}^{*}$ & $1.22 \mathrm{ab}^{*}$ & $1.52 b^{*}$ & $\ddagger$ & $\neq$ & $\neq$ & $0.97 \mathrm{ab}^{*}$ & $0.33 \mathrm{a}$ \\
\hline \multirow[t]{3}{*}{ Q } & $\mu \mathrm{G}^{\prime}$ & $0.48 b^{*}$ & $0.74 b^{*}$ & $\S$ & $\neq$ & $\neq$ & 末 & $\S$ & $-0.04 \mathrm{a}$ \\
\hline & NI & $0.57 \mathrm{ab}^{*}$ & $0.83 \mathrm{~b}^{*}$ & $0.62 \mathrm{ab}^{*}$ & $\ddagger$ & * & $\neq$ & $0.68 b^{*}$ & $0.03 \mathrm{a}$ \\
\hline & & & & & $E P 58 \times H$ & & & & \\
\hline \multirow[t]{2}{*}{ A } & $\mu \mathrm{G}^{\prime}$ & $-0.22 \mathrm{ab}$ & $-0.16 \mathrm{ab}$ & $0.74 \mathrm{~d}^{*}$ & $\ddagger$ & $0.50 \mathrm{~cd}^{*}$ & $-0.60 \mathrm{a}$ & $0.52 \mathrm{~cd}^{*}$ & $0.10 \mathrm{bc}$ \\
\hline & NI & $-0.52 \mathrm{ab}$ & $-0.76 \mathrm{ab}$ & $0.18 \mathrm{c}$ & $\ddagger$ & $-0.16 b c$ & $-1.06 \mathrm{a}$ & $-0.18 b c$ & $-0.48 \mathrm{abc}$ \\
\hline \multirow[t]{2}{*}{ S } & $\mu \mathrm{G}^{\prime}$ & $0.78 b^{*}$ & $0.42 \mathrm{ab}$ & $1.52 \mathrm{c}^{*}$ & $\ddagger$ & $1.56 \mathrm{c}^{*}$ & $-0.24 \mathrm{a}$ & $0.91 \mathrm{bc}^{*}$ & $0.59 b^{*}$ \\
\hline & NI & $0.05 \mathrm{abc}$ & $-0.04 \mathrm{ab}$ & $1.07 \mathrm{c}^{*}$ & $\ddagger$ & $0.79 b^{*}$ & $-0.92 \mathrm{a}$ & $0.26 \mathrm{bc}$ & $0.27 \mathrm{bc}$ \\
\hline \multirow[t]{2}{*}{ Q } & $\mu \mathrm{G}^{\prime}$ & $\S$ & $0.49 a b^{*}$ & $0.75 b^{*}$ & $\ddagger$ & $\S$ & $0.12 \mathrm{a}$ & $\S$ & $0.43 \mathrm{ab}^{*}$ \\
\hline & NI & $0.93 \mathrm{a}^{*}$ & $0.62 a^{*}$ & $0.83 \mathrm{a}^{*}$ & $\ddagger$ & $0.68 a^{*}$ & $0.38 \mathrm{a}$ & $0.74 \mathrm{a}^{*}$ & $0.51 \mathrm{a}^{*}$ \\
\hline
\end{tabular}

${ }^{2} \mu \mathrm{G}^{\prime}$ as defined by Dudley (1987) and NI as defined by Bernardo (1990).

${ }^{\mathrm{y}} \mu \mathrm{G}^{\prime}$ could not be calculated: it was impossible to solve a necessary equation (Dudley, 1987).

xIn the field we could not obtain the necessary hybrids to calculate the estimators.

*Exceeded twice the standard error. Means with the same letter within the same row do not differ significantly $\left(\operatorname{LSD}_{0.05}\right)$.

1993. Changes in characteristics of kernels in a population of shrunken2 maize selected for improved field emergence and increased kernel weight. J. Amer. Soc. Hort. Sci. 118:135-140.

Malvar, R.A., M.E. Cartea, P. Revilla, and A. Ordás. 1997a. Identification of field corn inbreds adapted to Europe to improve agronomic performance of sweet corn hybrids. Crop Sci. 37:1134-1141.

Malvar, R.A., P. Revilla, M.E. Cartea, A. Butrón, and A. Ordás. 2001. Checking performance of field corn inbreds as donors of favorable alleles to improve early vigor and adaptation of sweet corn hybrids to European conditions. Maydica 46:187-193.

Malvar, R.A., P. Revilla, M.E. Cartea, and A. Ordás. 1997b. Field corn inbreds to improve sweet corn hybrids for early vigor and adaptation to European conditions. Maydica 42:247-255.

Mercy T., J.F. Cheres, and S. Knapp. 1999. Donor inbred lines for enhancing the performance of single-cross sunflower hybrids. Crop Sci. 39:1325-1331

Metz, G. 1994. Probability of net gain of favorable alleles for improving an elite single cross. Crop Sci 34:668-672.

Misevic, D. 1989a. Identification of inbred lines as a source of new alleles for improvement of elite maize single crosses. Crop Sci. 29:1120-1125.

Misevic, D. 1989b. Evaluation of three test statistics used to identify maize inbred lines with new favorable alleles not present in elite single cross. Theor. Appl. Genet. 77:402-408. 
Ordás, A., P. Revilla, R.A. Malvar, and M.E. Cartea. 1994. Development of sweet corn hybrids adapted to the environmental conditions of the northwest of Spain. Maydica 39:171-175.

Revilla, P. 1992. Estudio de los factores genéticos y ambientales que condicionan la adaptación del maíz dulce a Galicia. PhD Diss. Univ. of Santiago de Compostela, Spain.

Rhodes A.M, E.E. Carey, and D.B. Dickinson. 1982. Illinois sweet corn inbreds with the suse genotype. HortScience 17:411-412.

Scott, G.C., R.O. Belkengrew, and E.C. Ritchell. 1945. Maturity of sweet corn determined by the refractometer. Food Industry 17:1030-1032.

Soberalske, R.M. and R.H. Andrews. 1978. Gene effects on kernel moisture and sugars of near isogenic lines of sweet corn. Crop Sci. 18:743-746.

Soberalske, R.M. and R.H. Andrews. 1980. Gene effects on water soluble polysaccharides and starch of near-isogenic lines of sweet corn. Crop Sci. 20:201-204.

Sprague, G.F. and S.A. Eberhart. 1977. Corn breeding, p. 305-362. In:
G.F. Sprague (ed.). Corn and corn improvement. 2nd ed. Amer. Soc. Agron., Madison, Wis.

Sprague, C.F. and L.A. Tatum. 1942. General vs. specific combining ability in single crosses of corn. J. Amer. Soc. Agron. 34:923-932.

Steel, R.G.D., J.H. Torrie, and D.A. Dickey. 1997. Principles and procedures of statistics: A biometrical approach. 3rd ed. McGraw-Hill, New York.

Tracy, W.F. 2001. Sweet corn, p. 155-198. In: A.R. Hallauer (ed.). Specialty corns. 2nd ed. CRC, Boca Raton, Fla.

Wann, E.V. 1980. Seed vigor and respiration of maize kernels with different endosperm genotypes. J. Amer. Soc. Hort. Sci. 105:31-34.

Zanoni, U. and J.W. Dudley. 1989a. Comparison of different methods of identifying inbreds useful for improving elite maize hybrids. Crop Sci. 29:577-582.

Zanoni, U. and J.W. Dudley. 1989b. Testcross evaluation of $F_{2}$ populations from maize inbreds selected for unique favorable alleles. Crop Sci. 29:589-595. 